\title{
SACCADIC DISPLACEMENTS OF THE RETINAL IMAGE: EFFECTS ON THE VISUAL SYSTEM IN THE CAT
}

\author{
M. JEANNEROD ${ }^{1}$ and G. ChOUVET \\ Laboratoire de Médecine Expérimentale, Faculté de Médecine, Lyon
}

(Received 13 March 1972; in revised form 5 May 1972)

\section{INTRODUCTION}

THE EXPERIMENTS reported below were aimed at elucidating a perceptual event associated with saccadic eye movements, generally referred to as "saccadic suppression". In man, the occurrence of a saccade corresponds to a rise in psycho-physical threshold for the perception of dim flashes (Latour, 1962; VolkMAN, Schick and RigGS, 1968; ZuBER and STARK, 1966), or letters (UTTAL and SMITH, 1968); this effect starts some $40 \mathrm{msec}$ prior to the onset of the saccade, and lasts some $100 \mathrm{msec}$, i.e. up to the beginning of the next fixation. Similarly, cortical responses evoked by light flashes (DUFFY and LOMBroso, 1968), or by a brief pattern shift presented at the time of a saccade (Gross, VAUGHAN and VALENSTEIN, 1967) are reduced in amplitude, with the same time course. These phenomena were also investigated at a neurophysiological level in animals, with the idea that a central mechanism related to the activation of the oculomotor system would reduce the transmission of retinal information to the higher visual centers. Changes in the excitability of intrageniculate optic terminals (and interpreted as a pre-synaptic inhibition) were observed in pre-trigeminal cats, in relation with following eye movements (KAWAMURA and MARCHIAFAVA, 1968), and in normal cats, in relation with rapid eye movements of sleep (BIZZl, 1966b). However, Cohen, FeLdman and Diamond (1969), in the alert monkey, could not find any significant change in the geniculate or calcarine responses to optic tract stimulations during saccades. A similar negative result was reported by MALCOLM, BRUCE and BURKE (1970), in the cat, when the animal is in complete darkness, although in light the geniculate response is reduced in amplitude during saccades.

Another alternative explanation would be that the visual, rather than the motor component of the saccade would influence optic transmission. This hypothesis, already put forward by several authors (see Discussion) may be tested in experimental situations where a displacement of the retinal image occurs without displacement of the eye. Results to be reported here, obtained in paralyzed cats, by recording visual responses evoked by flashes paired with fast movements of a pattern, confirm the importance of a purely visual factor in saccadic suppression.

\section{METHODS}

Ten adult cats were used. Under ether anaesthesia, the trachea and a femoral vein were cannulated, the skull was exposed, and drill holes were made above the location of the lateral geniculate bodies, of the right superior colliculus and posterior visual cortex. The animal was then paralysed with i.v. Flaxedil, artificially ventilated and rewarmed, and the anaesthesia was discontinued. Wounds and pressure points were infiltrated repeatedly with $1 \%$ Procaine.

1 Present ađdress: Unité de Recherches sur la Physiopathologie du Système Nerveux, Lyon-Bron, 69, France. 
The animal remained fixed in a stereotaxic apparatus designed for visual studies, allowing stimulation of the entire visual field (LPC, Paris). Both eyes were dilated with atropine sulfate, and lids were maintained retracted with Neosynephrine. One eye or the other could be easily covered.

The cat faced a white tangent screen, at $1 \mathrm{~m}$ from the eye, and normal to the plane of gaze, in a dimly lit room. Two types of stimuli were projected onto the screen:

1. Rectangular patterns $\left(40 \times 50 \mathrm{~cm}\right.$, subtending about $\left.25^{\circ}\right)$, made of alternating dark and lighted stripes, or squares, or of dark grids on a bright background. Luminance was about $2 \times 10^{-3} \mathrm{~cd} / \mathrm{cm}^{2}$ for the bright areas of the pattern, and $l \times 10^{-4}$ for the dark areas. The pattern could be moved horizontally by reflecting the projector beam on a small mirror attached to a galvanometer. A stop was inserted in the system so that only the pattern would move, and the extent of the image would remain unchanged. The galvanometer was fed with adjustable ramps of current from a generator. The resulting displacement of the pattern was of a constant amplitude (about $7 \mathrm{~cm}, 3 \cdot 5^{\circ}$ ), but could be varied in speed (from $30^{\circ} / \mathrm{sec}$ to about $300^{\circ} / \mathrm{sec}$ ), and direction (to the right or to the left).

2. One msec flashes of light (discs $9 \mathrm{~cm}$ dia., about $5^{\circ}$ ) appearing near the center of the pattern, and produced by a neon tube. Their intensity was filtered until it matched subjectively the intensity of the brightest parts of the pattern. Their exact position on the pattern was adjusted so as they would project on areas of comparable luminance (e.g. bright squares) throughout the same experiment whether the pattern was stationary or moving. The center of the pattern and consequently, the flash, were positioned on the screen close to the visual axis of the animal. However, because of the relatively large size of the stimuli, no attempt was made to locate them more precisely relatively to the projection of the area centralis.

Movement of the pattern (which we will refer to as "test-movement"), and presentation of the flash were paired through cycles of stimulation, programmed on the ramp generator. Usually, the test-movement was followed by a $1 . \mathrm{sec}$ epoch during which the pattern remained in the position of deviation; then the initial position was restored by a slow $\left(30^{\circ} / \mathrm{sec}\right)$ return movement, and maintained during $3 \mathrm{sec}$ more before a new cycle started. The flash could be triggered by the onset of the test-movement $\left(t_{0}\right)$, or delayed from $t_{0}$ by up to $250 \mathrm{msec}$. In other experiments, the flash was delivered before the test movement (negative delays), up to $t_{0}-100 \mathrm{msec}$. In addition, control experiments were performed, by presenting the flash on the stationary pattern, or by presenting the test-movement without flash. Due to the averaging technique (see below) the same type of cycle (direction, speed of the test-movement, delay of the fiash from $t_{0}$ ) was repeated 50 or 100 times.

Bipolar nichrome electrodes (tip separation, $500 \mu$ ) were implanted stereotaxically. The activity was amplified on Tektronix type 122 amplifiers (bandpass, $1-250 \mathrm{~Hz}$ ), displayed on an uscilloscope, and processed on-line with a multichannel analyser (Intertechnique Didac 800). Activity was averaged through successive cycles, during 400 or $600 \mathrm{msec}$ after $t_{0}$ when the test-movement occurred first, or after the flash when the delay was negative. Algebraic summation of the potentials generated by the two stimuli was tested in some experiments. The curve obtained with the test-movement alone was stored, and subsequently subtracted from the curve obtained with the paired stimuli.

\section{RESULTS}

\section{Test-movement without flash}

A saccadic like displacement of the image of a pattern across the stationary retinae induces a large biphasic potential (movement potential) which can be recorded in the lateral geniculate body, in the superior colliculus, and in the visual cortex (Fig. 1), as already shown in chronic preparations (JEANNEROD and SAKAI, 1971). The initial polarity depended upon the location of the electrode tip: for instance, in the optic radiations above the lateral geniculate body, the initial polarity was positive, but, when the electrode penetrated the nucleus, polarity inverted and became negative. For a given location of the electrode tip, the initial polarity was the same as that of the flash evoked response (see for instance Figs. 1 and 3). Latency of the averaged movement potential was $35-45 \mathrm{msec}$, i.e. significantly longer than that of the flash response $(17-25 \mathrm{msec}$, in the same conditions). Amplitude of the movement potential, in the lateral geniculate body, as well as in the optic radiations was maximal when both eyes were stimulated. Occlusion of one eye reduced the amplitude by about one half.

Reversal of the direction of the test-movement did not alter either the waveform or the polarity of the movement potential (Fig. 1). However, the amplitude of the movement 

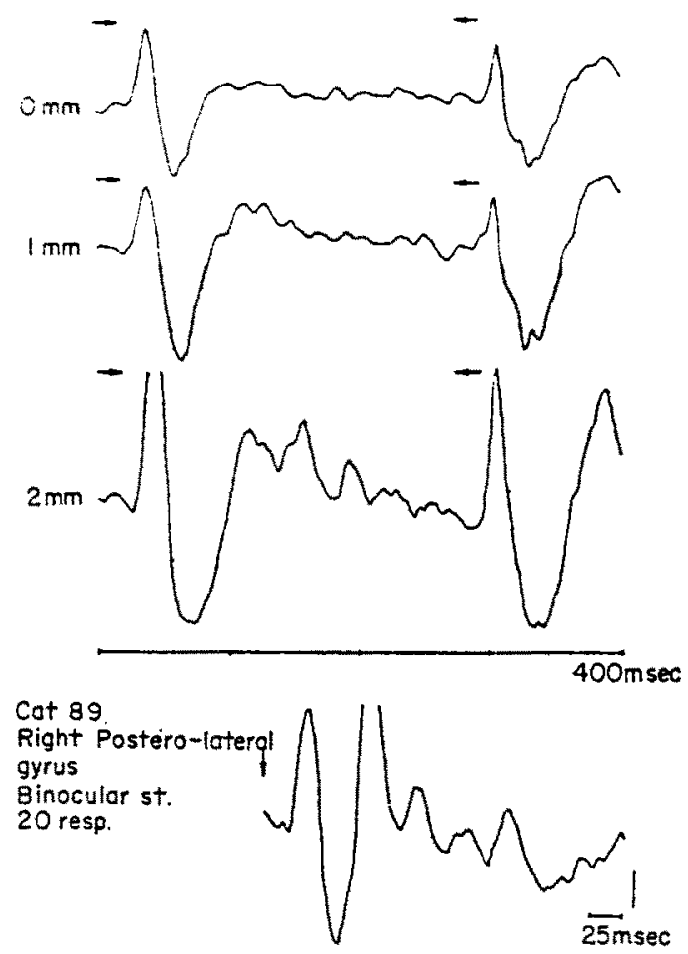

Fig. 1. Averaged movement potentials from the visual cortex, in response to a left to right and right to left displacement of the pattern. Numbers on the left indicate the depth of the electrode relative to the cortical surface. Lower row: potential evoked by flashing the spot at the center of the stationary pattern, the electrode tip being at $2 \mathrm{~mm}$ under the cortical surface.

In this and subsequent figures, horizontal arrows indicate the onset of the test-movement, and vertical arrows, the onset of the flash. Vertical calibration, $100 \mu \mathrm{V}$.
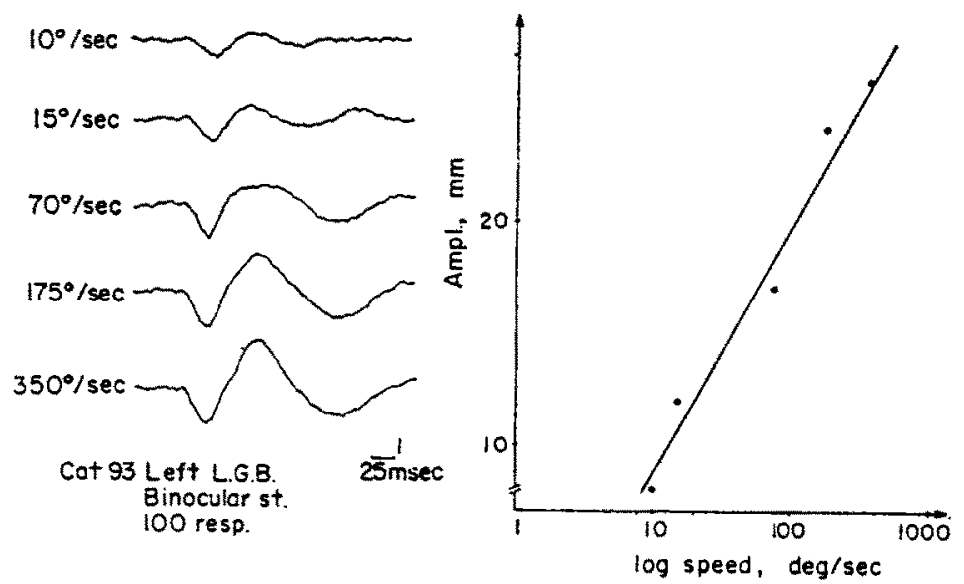

FIG. 2. Geniculate averaged movement potentials in response to pattern displacements of increasing speed (see indication of the speed in degrees/second, on the left). Diagram on the right shows the relationship between potential amplitude and the log of the speed. 
potential was found related to the speed of the test-movement. Figure 2 shows a fairly linear relationship between potential amplitude and the $\log$ of the angular speed of the movement.

The waveform of the movement potential was found rather independent of the structure of the pattern. However, its amplitude tended to increase with the spatial frequency of the pattern, and with the extent of its displacement, for instance, when the displacement affected the whole image (pattern + contours) rather than the pattern only.

Thus, the characteristics of the movement potentials described here are closely similar to those described in man (by surface EEG recordings) in relation with pattern reversal (COBB, Morton and ETtLinger, 1967), or with accelerated visual motion (MACKAY and RietVeld, 1968; Clarke, 1972).

\section{Test-movement paired with flash}

a. Positive delays (test-movement precedes flash). With relatively long delays (i.e. longer than $200 \mathrm{msec}$ ), potentials evoked by the two stimuli were clearly distinct from each other, and their waveform and amplitude did not differ from those obtained in control cycles. But when the delay was shortened, interactions between the two responses was observed. Figure 3 can be considered as a good example of such interactions: the response to the

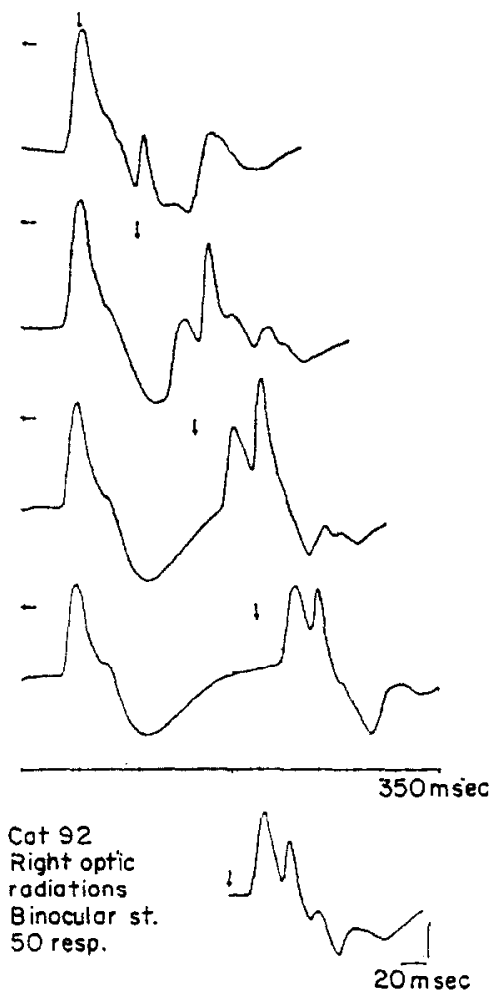

FIG. 3. Interaction, at the supra-geniculate level, between movement potentials and flash evoked potentials. In this experiment, the test movement was a fast $(600 \% / \mathrm{sec})$ leftward pattern displacement. Flashes were presented at $50 \mathrm{msec}$ (upper record), 100, 150, $200 \mathrm{msec}$ after the onset of the test movement. Lower row: potential obtained by flashing the spot at the center of the stationary pattern. 


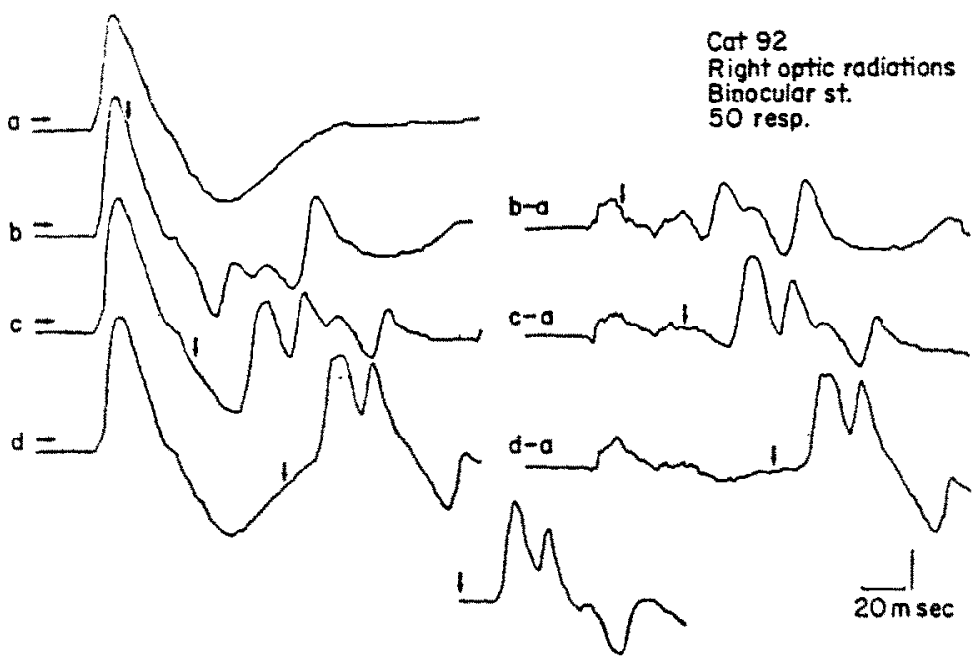

FIG. 4. Same experiment as in Fig. 3. Record a is averaged movement potentials obtained by presenting the test movement alone. Records $b, c$, d, are averaged curves obtained by pairing test movement and flash with positive delays of 50,100 and $150 \mathrm{msec}$, respectively. Records on the right are the result of digital subtraction of the movement potential (record a) from records $b, c$, and d. Lower record: potential obtained by flashing the spot on the stationary pattern.

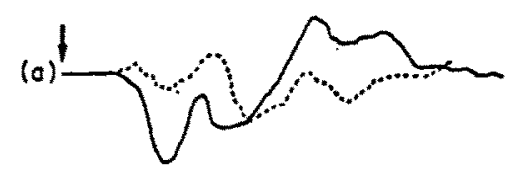

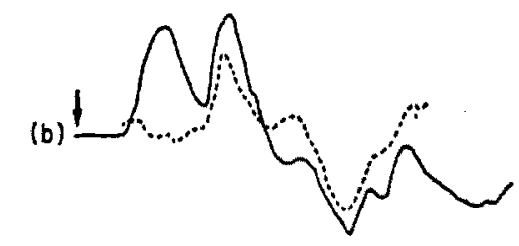

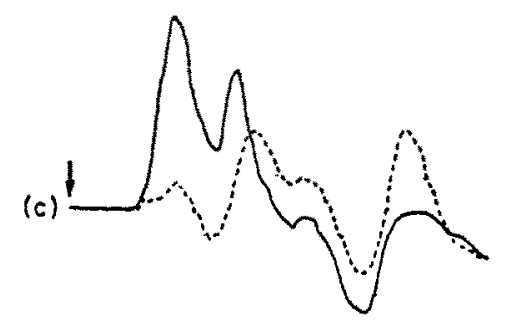

$\widetilde{20 \mathrm{msec}}$

FIG. 5. Comparison between flash evoked potential obtained in "control" conditions with flash evoked potential obtained by subtracting the movement potential as in Fig. 4. a: records obtained from the Lateral Geniculate Body, $b$ and $c$ : records from the visual radiations. Records c are redrawn from Fig. 4. In all records, the "subtracted" potential (dotted line) is obtained from records where test movement and flash were paired with a 50 -msec positive delay. 
flash was generally of a greater amplitude (20-30 per cent greater than the control) when the flash was presented at about $150 \mathrm{msec}$ after the onset of the test-movement. When the delay between the two stimuli was further reduced, the response to the flash tended to decrease in amplitude. Maximum depression occurred when the initial component of this response coincided with the slow wave following the movement potential. Figures 3 and 4 (left) clearly show the absence of the early peak from the response evoked by a flash presented $50 \mathrm{msec}$ after the test-movement. Subtraction of the movement potential from the whole curve confirms the lack, or at least the strong depression of this component of the response, and shows that the other components still occur at the same delay from the flash onset than in control responses, even though they are also depressed in amplitude (Figs. 4, right, and 5).

The movement potential was little altered compared to the flash response. However, it was constantly of a larger amplitude when the test-movement preceded the flash by less than $100 \mathrm{msec}$ (Fig. 3).

b. With negative delays (flash precedes test-movement). The movement potential presented fundamentally the same type of changes than those described in the previous section, concerning the response to flash, i.e. mainly a strong depression for the -30 to $-50 \mathrm{msec}$ delays. The response to flash was similarly reduced in amplitude for about the same delays. Pairing flash and test-movement with "negative delays", thus resulted in a strong depression of both responses in the -30 to $-50 \mathrm{msec}$ zone (Fig. 6).

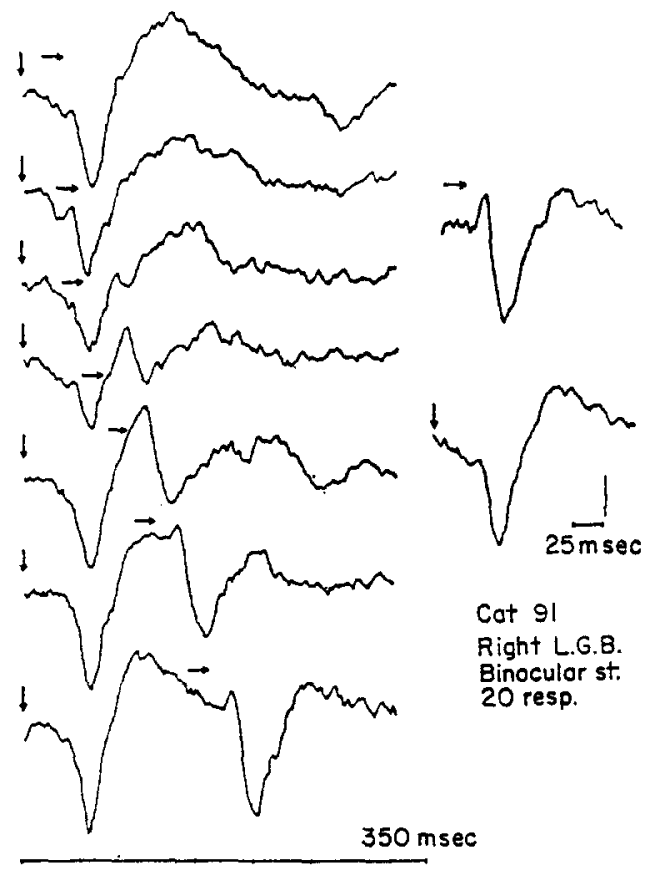

FIG. 6. Interaction, at the geniculate level, between flash evoked potentials and movement potentials. In this experiment, flash was presented at $20 \mathrm{msec}$ (upper record), 30, 40, 50, 70, $100,130 \mathrm{msec}$ (subsequent records) before the onset of the test movement (negative delays). Upper record on the right: movement potential obtained by presenting the test movement alone. Lower record on the right: potential evoked by flashing the spot at the center of the stationary pattern. 
None of the interactions reported in this paper were observed when the speed of the test-movement was slower than 200 or $300 \%$ sec.

\section{DISCUSSION}

Transmission of the signals generated by localized changes in luminance is altered by the brisk displacement of a pattern across the retina. This conclusion was first reached by MACKAY (1970) who demonstrated that a small dim flash may not be perceived by the subject if presented at the time of the saccadic-like motion of a larger spot in front of the stationary eyes. In his experiment, psycho-physical "suppression" for the flash was maximal when it was timed to occur between $40 \mathrm{msec}$ before and $100 \mathrm{msec}$ after the displacement. Our results show that this rise in perceptual threshold corresponds, at least for the "positive" delays, to a depression of the potential generated by the flash in the central visual pathways. Accordingly, it is tempting to generalize this effect of retinal image motion, to situations where "saccadic suppression" has been invoked to account for a similar rise in perceptual threshold (and for a similar depression in evoked potentials), i.e. active saccades (see references in the Introduction), and passive displacements of the eyeball (RICHARDS, 1968, 1969). This generalization is further supported by the fact that suppression during active saccades is strongly dependent upon the content of the visual field: suppression decreases when the stimulus presented during the saccade is uniform rather than structured; it is absent when the stimulus is displaced synchronously with the saccade, i.e. when it stays on the same retinal locus during the eye movement; and it tends to disappear when the stimulus is presented under low luminance levels (Mitrani, Mateeff and YaKimoff, 1970, 1971, see also KraUSKOPF, GRAF and GAARDER, 1966). Image motion over the retina (displacement of the field before stationary eyes, or displacement of the eyes across a stationary field) may thus be considered as a sufficient factor to cause a concomitant alteration in perception.

This interaction between a stationary flash and a moving pattern in fact represents another example of visual "masking", like, for instance, the rise in brightness detection threshold in relation with brief flashes (CRAWFORD, 1947), or in relation with transition from dark to light, or from light to dark (BAKER, 1963). Similarly, when two flashes of equal intensity are presented at very short intervals, in man, the amplitude of the potential evoked by the second flash is strongly depressed for intervals shorter than $50 \mathrm{msec}$, and then enhanced for intervals around 100 msec (CiganeK, 1964; Bergamasco, 1966). This time course is closely similar to that we have observed by pairing a flash and a moving pattern. In addition, in our experiments, the order of presentation of the two stimuli was not critical, since the flash response was "masked" by the movement potential in the "positive delays" experiments, whereas the reverse occurred with "negative delays".

It is thus clear that the competition between displacements of the retinal image and perception of other stimuli is only contingent to a particular association, as occurs in eye movements, or in experimental situations like we are describing here. The explanation of this phenomienon should lie in the characteristics of the transfer of information along the visual pathways (see DONCHIN and LiNDSLEY, 1965), rather than in a specific mechanism such as an involvement of "oculomotor" projections to the visual centers (see Introduction). This, of course, does not exclude that eye movements nevertheless exert a central influence on the visual system. Changes in neuronal firing have been demonstrated (in cats) at the geniculate level in relation with active saccades, and in the absence of visual input 
(Bizzi, 1966a; JeANNerod and PUtKonen, 1971; Lombroso and CorrazZA, 1971). But these saccade-locked discharges start several tens of milliseconds after saccade onset, which logically excludes that they would account for such an early phenomenon as "saccadic suppression".

Acknowledgements-The assistance of J. KRUGER, Abteilung für Neurophysiologie, Freiburg i. B. Germany, and of F. Peronvet, Unité de Recherches sur la Physiopathologie du Système Nerveux, Lyon. France, is gratefully acknowledged.

\section{REFERENCES}

BAKER, H. D. (1963) Initial stages of dark and light adaptation. J. opt. Soc. Am. 53, 98-103.

BERGaMasco, B. (1966). Excitability cycle of the visual cortex in normal subjects during psychosensory rest and cardiazolic activation. Brain Res. 2, 51-60.

Bizzi, E. (1966a). Discharge patterns of single geniculate neurons during the rapid eye-movements of sleep. J. Neurophysiol. 29, 1087-1095.

BizzI, E. (1966b). Changes in the orthodromic and antidromic response of optic tract during the eyemovements of sleep. J. Neurophysiol. 29, 861-870.

CiganeK, L. (1964). Excitability cycle of the visual cortex in man. Ann. N.Y. Acad, Sci, 112, 241-253.

CLARKE, P. G. H. (1972). Visual evoked potentials to sudden reversal of the motion of a pattern. Brain Res. $36,453-458$.

COBb, W. A., Morton, A. B. and Ettlinger, G. (1967). Cerebral potentials evoked by pattern reversal and their suppression in visual rivalry. Nature, Lond. 216, 1123-1125.

COHEN, B., Feldman, M. and Diamond, S. D. (1969). Effects of eye-movements, brainstem stimulation and alertness on transmission through lateral geniculate body of monkey. J. Neurophysiol. 32, 583-594.

CRAWFORD, B. H. (1947). Visual adaptation in relation to brief conditioning stimuli. Proc. R. Soc. B. 134, 283-302.

DONCHIN, E. and LINDSLEY, D. B. (1965). Retroactive brightness enhancement with brief paired flashes of light. Vision Res. 5, 59-70.

DUFFY, F. H. and Lombroso, C. T. (1968). Electrophysiological evidence for visual suppression prior to the onset of a voluntary saccadic eye-movement. Nature, Lond. 218, 1074-1075.

Gross, E. G., VAuGhaN, H. G. and VALENSTEIN, E. (1967). Inhibition of visual evoked responses to patterned stimuli during voluntary eye-movements. Electroenceph. clin. Neurophysiol. 22, $204-209$.

JEANNEROD, M. and PUTKONEN, P. T. S. (1971). Lateral geniculate unit actipity and eye movements: saccade locked changes in dark and in light. Exp. Brain Res. 13, 533-546.

JeANNEROD, M. and SAKAI, K. (1971). Potentials related to visual field motions as compared to eye-movement potentials in the cat's visual system. Vision Res. 11, 161-165.

Kawamura, H. and Marchiafava, P. L. (1968). Excitability changes along visual pathways during eye tracking movements. Arch. Ital. Biol. 106, 141-156.

KRAUSKOPF, J., GRAF, V. and GAARDER, K. (1966). Lack of inhibition during unvoluntary saccades. Am. J. Psychol. 79, 73-81.

LATOUR, P. L. (1962). Visual threshold during eye-movements. Vision Res. 2, 261-262.

Lomproso, C. T. and CorazzA, R. (1971). Central visual discharge time locked with spontaneous eye movements in the cat. Nature, Lond. 230, $464-467$.

MACKAY, D. M. (1970). Elevation of visual threshold by displacement of retinal image. Nature, Lond. 225. 90-92.

MACKAY, D. M. and RreTveLD, W. J. (1968). Electroencephalogram potentials evoked by accelerated visual motion. Nature, Lond. 217, 677-678.

MALCOLM, L. I., BRUCE, I. S. C. and BURKE, W. (1970). Excitability of the lateral geniculate nucleus in the alert, non alert and sleeping cat. Exp. Brain Res. 10, 338-397.

MITRAN, L. MATEEF, S. T. and YAKIMOFF, N. (1970). Smearing of the retinal image during voluntary saccadic eye-movements. Vision Res. 10, $405-410$.

MrTRAN, L. MATEEFF, S. T. and YAKIMOFF, N. (1971). Is saccadic suppression really saccadic? Vision Res. 11 , $1157-1162$.

Richards, W. (1968). Visual suppression during passive eye-movements. J. opt. Soc. Am. 58, 1159-1160.

Richards, W. (1969). Saccadic suppression. J. apt. Soc. Am. 59, 617-623.

UTTAL, W. R. and SMITH, L. (1968). Recognition of alphabetic characters during voluntary eye-movements. Percept. \& Psychophys. 3, 257-264.

Volkmann, F. C., Schick, A. M. L. and Riggs, L. A. (1968). Time course of visual inhibition during voluntary saccades. J. opt. Soc. Am. 58, 562-569.

ZUBER, B. L. and STARK, L. (1966). Saccadic suppression: elevation of visual threshold associated with saccadic eye-movements. Exp. Neurol. 16, 65-79. 


\begin{abstract}
Electrical activity of lateral geniculate nucleus, optic tract and visual cortex was recorded in cats paralysed with curare. The responses to a low intensity flash of light were studied when the flash was associated with the sudden movement $\left(>300^{\circ} / \mathrm{sec}\right.$ ) on the retina of an image involving contours. When the flash occurred $50 \mathrm{msec}$ after the beginning of the movement, the response was strongly diminished in amplitude, and was normal again if the delay between both stimuli became longer than $200 \mathrm{msec}$. When the flash occurred before the movement, it was on the contrary the potential induced by the movement which was reduced in amplitude with the same delays. These results show that any movement on the retina of a structured image may alter the signals of stationary stimuli. It would be possible to explain on these lines the perceptive "suppression" observed during rapid ocular movements.
\end{abstract}

Résumé-On enregistre l'activité électrique du corps genouillé latéral, du tractus optique et du cortex visuel chez des chats paralysés au curare. On étudie les réponses à un éclair de lumière de faible intensité quand l'éclair est associé avec un mouvement brusque ( $\left.>300^{\circ} / \mathrm{sec}\right)$ sur la rétine d'une image comprenant des contours. Quand l'éclair se produit environ $50 \mathrm{msec}$ avant le début du mouvement, l'amplitude de la réponse diminue fortement, et redevient normale si le dèlai entre les deux stimuli dépasse $200 \mathrm{msec}$. Quand l'éclair précède le mouvement, c'est au contraire le potentiel dû au mouvement dont l'amplitude est réduite avec les mèmes délais. Ces résultats montrent que tout mouvement sur la rétine d'une image structurée peut altérer les signaux d'un stimulus stationnaire. On pourrait expliquer ainsi la "suppression" perceptive que l'on observe durant des mouvements oculaires rapides.

Zusammenfassung-Die elektrische Aktivität wurde im Geniculatum laterale, im Sehnerv und im visuellen Kortex bei Katzen gemessen, die mit Curare geiähmt waren. Die Antwort auf einen Lichtblitz niedriger Intensität wurde in Verbindung mit der plötzlichen Bewegung ( $>300^{\prime}$ ' sek.) eines konturenreichen Bildes untersucht. Wenn der Blitz 50 msek. nach Beginn der Bewegung kam, wurde die Antwort darauf stark geschwächt. Sie war wieder normal, wenn der Zeitunterschied zwischen beiden Reizen mehr ais 200 msek. betrug. Wenn der Blitz vor der Bewegung kam, wurde das durch die Bewegung indurierte Potential bei den gleichen Verzögerungen geschwächt. Diese Ergebnisse zeigen, dass jede Bewegung eines strukturierten Bildes auf der Netzhaut, die Antwort auf stationäre Reize ändern kann. Es sollte möglich sein. damit die während schneller Augenbewegungen beobachtete Suppression zu erklären.

Резюме-У кошек парализованных Кураре была зарегистрирована злектркческая активность латерального коленчатого тела, зритетьно тракта и зрительнои коры. Были исследованы реахшии ва вспышки света низкой интенсивности, когда вспышка ассошинровалась со стремдетльным двнженвем (>300\% сек) по сетчатке контурного нзобрахения. Когда вспышка появлялась через 50 мсек после начала двғкения, реакция была сильо уменшена по амтитуде и была снова нормапьои, если задержка была дольше 200 мсек. Еспи встытка появлялась перед двихендем, то напротив, потенциа. вызы ваемый двихекпем умень шался по амплитуде при том же самом запаздывании. Зти результаты показывают, что всякое двкжекпе структурированного изображенкя может изменять сигнал, даваемый сташнонарным стимулом. Было бы возможно объяснить зтнм путем "подавление" восприятия, наблюдаемое во время быстрого движенкя глаз. 